\title{
Characterization of attenuated Renibacterium salmoninarum strains and their use as live vaccines
}

\author{
J. G. Daly ${ }^{1, *}$, S. G. Griffiths ${ }^{2}$, A. K. Kew ${ }^{3}$, A. R. Moore ${ }^{3}$, G. Olivier $^{3}$ \\ ${ }^{1}$ Division of Natural Sciences, Purchase College, State University of New York, Purchase, New York 10577, USA \\ ${ }^{2}$ Research and Productivity Council, 921 College Hill Rd, Fredericton, New Brunswick E3B 6Z9, Canada \\ ${ }^{3}$ Department of Fisheries and Oceans, Gulf Fisheries Centre, PO Box 5030, Moncton, New Brunswick E1C 9K1, Canada
}

\begin{abstract}
Two nutritionally mutant strains of Renibacterium salmoninarum (Rs) were isolated that grew on tryticase soy agar (Rs TSA1) or brain heart infusion agar (Rs BHI1). These 2 strains could be continuously cultured on these media, whereas typical $R$. salmoninarum would only grow on KDM-2 agar. We determined no other phenotypic difference that could be used to distinguish them from wild-type $R$. salmoninarum. Both strains were found to be avirulent when $5 \times 10^{6}$ bacteria were intraperitoneally (IP) injected into Atlantic salmon. Rs TSA1, Rs BHI1, and Rs MT-239 (a R. salmoninarum strain previously shown to be attenuated) were tested as live vaccines in 2 separate trials. The best protection was seen with Rs TSA1. Vaccinated Atlantic salmon had relative percent survival (RPS) of 50 at $74 \mathrm{~d}$ post-challenge in Trial 1 and 76 at $60 \mathrm{~d}$ post-challenge in Trial 2. In both trials, $100 \%$ of the control salmon died from bacterial kidney disease (BKD) (within $40 \mathrm{~d}$ for Trial 1 and $50 \mathrm{~d}$ for Trial 2) after IP challenge with $5 \times 10^{6}$ live cells of the virulent isolate Rs Margaree.
\end{abstract}

KEY WORDS: Bacterial kidney disease $\cdot$ Renibacterium salmoninarum

Resale or republication not permitted without written consent of the publisher

\section{INTRODUCTION}

Bacterial kidney disease (BKD), caused by the Grampositive bacterium Renibacterium salmoninarum, is a serious disease of salmonid fish that is transmitted both horizontally and vertically. In clinically diseased fish large numbers of viable bacteria are typically found within macrophages. The presence of the bacterium within macrophages, and the production of granulomatous lesions found with $\mathrm{BKD}$, are distinctive features of facultative, intracellular pathogens. Despite extensive research, successful chemotherapy or immunotherapy protocols are not available to efficiently prevent or cure BKD (Young \& Chapman 1978, Evelyn 1993, Fryer \& Lannan 1993, Griffiths et al. 1998).

Renibacterium salmoninarum has been shown to survive and perhaps multiply within macrophages in vitro, as well as the RTG-2 and epithelioma papillosum cyprini (EPC) teleost cell lines (Gutenberger 1993,

*E-mail: jdaly@purchase.edu
Evelyn 1996, MacIntosh et al. 1997). Thus R. salmoninarum can accurately be described as an intracellular pathogen. Unlike bacterial pathogens such as Listeria or Salmonella, the mechanisms responsible for R. salmoninarum intracellular survival have not been forthcoming. The most important renibacterial protein that has been extensively studied is the p57 haemagglutinin protein. This protein has been shown to have numerous in vitro properties that include haemagglutination, leucoagglutination, and spermagglutination abilities. It also makes the bacterium hydrophobic and has been suggested to be a major virulence factor, since strains missing this protein are less virulent (Daly \& Stevenson 1987, 1989, 1990, Bruno 1988, Weins \& Kaattari 1991).

Renibacterium salmoninarum requires specialized media and long periods of time for growth in vitro. Typically the bacterium is grown on the serum and L-cysteine containing agar medium, KDM-2 (Evelyn 1977). However, in agar-containing media, the serum can be effectively replaced with charcoal and to a 
lesser extent starch (Daly \& Stevenson 1985). In broth media, serum and charcoal are not necessary for the growth of large quantities of the bacterium (Daly \& Stevenson 1985, 1993). This suggests that it may be possible to select for bacterial mutants that grow on agar media without the requirement for serum or charcoal. In this study, trypticase soy agar (TSA) and brain heart infusion agar (BHIA) were chosen for this purpose since these 2 media are typically used for growing less fastidious bacteria. Both of these media have previously been shown not to support the growth of the bacterium due to their lack of L-cysteine (required at an amount of 0.05 or $0.1 \%$ (Daly \& Stevenson 1993), and serum or charcoal (Daly \& Stevenson 1985).

Another atypical strain that was characterized in this study was Renibacterium salmoninarum MT239 (Rs MT-239) which has previously been reported to have reduced virulence (Bruno 1988). Rs MT-239 is unique because it has a reduced expression of the p57 on the bacterial cell surface (Bruno 1988, Daly \& Stevenson 1990, Senson \& Stevenson 1999). The protein is, however, excreted into broth culture media (Senson \& Stevenson 1999).

Currently there are no vaccines available to prevent $\mathrm{BKD}$. It is generally recognized that the best means to successfully immunize against intracellular pathogens is to develop cellular immunity as a means of increasing the bacterial killing activity of the macrophages. One means that may direct the host to develop cellular immunity is to immunize the animal with a live, attenuated strain of the bacterium. As a first step in producing cellular immunity in salmon towards Renibacterium salmoninarum, we have developed nutritionally mutant strains of $R$. salmoninarum which are avirulent. These and the previously described, attenuated strain Rs MT239 have been characterized and tested as live vaccines.

\section{MATERIALS AND METHODS}

Media. Unless stated otherwise, Renibacterium salmoninarum strains were grown at $18^{\circ} \mathrm{C}$ on agar plates of either KDM-2 agar (Evelyn 1977) or KDM-2 agar plus antibiotics (SKDM; Austin et al. 1983).

Renibacterial isolates. Renibacterium salmoninarum strains Margaree and Miramichi were typical, virulent $R$. salmoninarum isolated from Atlantic salmon Salmo salar in eastern Canada. $R$. salmoninarum MT239 is an attenuated isolate that has reduced concentrations of the p57 protein on its surface, is relatively hydrophilic but has the typical growth and nutrient requirements of R. salmoninarum (Bruno 1988, Senson \& Stevenson 1999). It was previously obtained from Dr David Bruno, FRS Marine Laboratory, PO Box 101, Victoria Rd., Aberdeen AB11 9DB, Scotland, UK.
Nutritionally mutant strains of Renibacterium salmoninarum capable of growth on either TSA (Difco) or BHI agar (Difco) were selected by growing $R$. salmoninarum Margaree on KDM-2 agar for $2 \mathrm{wk}$, washing the bacteria in peptone saline $(0.1 \%$ peptone in $0.85 \%$ $\mathrm{NaCl}$ ) and plating $10^{8}$ bacteria $\mathrm{ml}^{-1}$ onto either TSA or BHI agar. After 4 to 5 wk growth at $18^{\circ} \mathrm{C}$, isolated colonies were randomly selected and re-plated onto their respective isolation medium. After 3 further passages, 2 strains, 1 that grew on TSA (designated Rs TSA1) and 1 that grew on BHI agar (designated Rs BHI1), were randomly selected for further passage and characterization.

Isolate characterization. All strains were tested for typical Renibacterium salmoninarum characteristics. It was determined whether each strain was composed of Gram-positive rods, whether they were hydrophobic according to the salt aggregation test (Daly \& Stevenson 1987), whether they required KDM-2 agar for growth, and whether they reacted with a monoclonal antibody (4D3) against $R$. salmoninarum p57 (DiagXotics, Inc.) which was detected with a fluorescein labeled goat anti-mouse antibody (Bio-Rad Laboratories). All strains were also characterized for their haemolytic and proteolytic abilities. $\beta$-haemolytic activity was assessed by growth on either KDM-2 (Rs Margaree, Rs Miramichi and Rs MT-239 strains), TSA (Rs TSA1) or BHI (Rs BHI1) agars containing either 5\% sheep or $5 \%$ rainbow trout Oncorhynchus mykiss erythrocytes. Proteolytic activity was assessed by growth on either KDM-2 plus casein (Rs Margaree, Rs Miramichi and Rs MT-239), TSA plus casein (Rs TSA1) or BHI plus casein (Rs BHI1) (Daly \& Stevenson 1985). Further enzymatic activity of all strains was assayed using the API-ZYM system (Bio-Merieux) at $15^{\circ} \mathrm{C}$ by using whole live cells of individual bacterial strains incubated for $24 \mathrm{~h}$. The results were compared with previously described $R$. salmoninarum API-ZYM profiles (Bruno \& Munro 1986, Bandin et al. 1991).

Growth of Rs TSA1 and Rs BHI1 on various bacteriological agars. The ability of strains Rs Margaree, Rs TSA1, and Rs BHI1 to grow on KDM-2 agar (typically used to grow Renibacterium salmoninarum) was compared with their ability to grow on media that would typically not provide optimal nutritional components: TSA, BHIA and KDM-2 without L-cysteine or serum. An end point dilution method was used to compare growth on the different agar media (Daly \& Stevenson 1985). Briefly, serial 10-fold dilutions of bacteria suspended in peptone saline were prepared, and $25 \mu \mathrm{l}$ drops of each dilution were spotted onto duplicate plates of each medium. After $30 \mathrm{~d}$ of incubation at $15^{\circ} \mathrm{C}$, the highest dilution of the culture at which colonies were observed on spot plates was recorded as the end point dilution. 
$\beta$-haemolytic zones surrounding strains Rs MT-239, Rs TSA1 and Rs BHI1 were similar to those seen with the wild-type Rs Margaree strain. In addition, both Rs TSA1 and Rs BHI1 produced the typical APIZYM patterns described previously (Bruno \& Munro 1986, Bandin et al. 1991) and they were Gram-positive with typical $R$. salmoninarum size and shape. Most importantly, when examined at $1000 \times$ with an UVmicroscope, both Rs TSA1 and Rs BHI1 gave typical fluorescent reactions when reacted with the anti- $R$. salmoninarum p57 monoclonal antibody.

\section{Virulence of Renibacterium salmoninarum mutant strains}

The 3 mutant Renibacterium salmoninarum strains Rs TSA1, Rs BHI1 and Rs MT-239 were avirulent for $50 \mathrm{~g}$ Atlantic salmon after a challenge dose of $5 \times 10^{6}$. After 5 mo there were no mortalities from any of these 3 strains. Furthermore, none of the fish became lethargic or diseased. At this time, all of the bacteria appeared to have been cleared from the salmon, as $R$. salmoninarum was not cultured from the kidney. At dosages of $10^{8}$ bacteria per fish, Rs BHI1 caused no mortalities after 5 wk whereas both RS TSA1 and Rs MT-239 each killed 8\% (2 of 25) of the challenged salmon within this period. In all cases, the bacteria that were isolated had phenotypes similar to the strain that was injected. In contrast, the 2 wild-type strains, Rs Margaree and Rs Miramichi, killed $100 \%$ of the salmon within $15 \mathrm{~d}$ with a challenge dose of $10^{8}$ per fish and in 40 to $50 \mathrm{~d}$ with a challenge dose of $5 \times 10^{6}$ (Fig. 1; see also Figs. 2 \& 3 for additional Rs Margaree results).

\section{Vaccination of Atlantic salmon with attenuated Renibacterium salmoninarum}

The use of Rs TSA1, Rs BHI1 and Rs MT-239 as live vaccines were assessed in 2 separate experimental trials. In the first experimental trial (Fig. 2) formalinkilled Rs Margaree bacterin plus adjuvant, and live Rs Mt-239 provided no protection against BKD. Some limited protection was provided by live Rs BHI1 (RPS of 30 ), whereas Rs TSA1 protected $50 \%$ of the salmon from disease (RPS of 50) $74 \mathrm{~d}$ after challenge (Fig. 2). In the second experimental trial (Fig. 3), all treatments provided protection during the $60 \mathrm{~d}$ post-challenge. Fish vaccinated with killed bacterin plus adjuvant had a RPS of 36, Rs MT-239 vaccinated fish had a RPS of 44, Rs BHI1 vaccinated fish had a RPS of 60, whereas those vaccinated with Rs TSA1 had a RPS of 76 (Fig. 3).

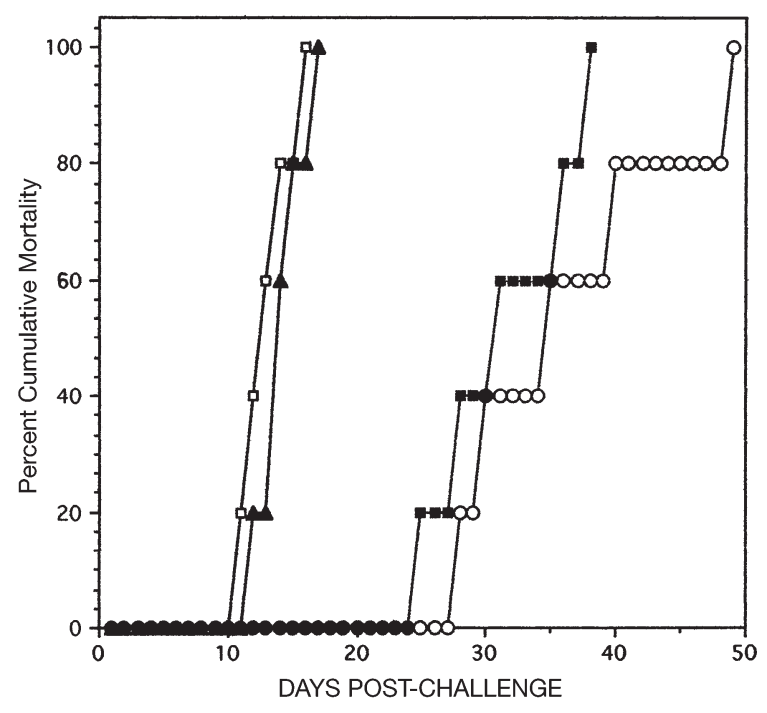

Fig. 1. Intraperitoneal challenge of Atlantic salmon Salmo salar with Renibacterium salmoninarum strains Rs Margaree and Rs Miramichi. Twenty-five salmon were injected intraperitoneally (IP) with $0.1 \mathrm{ml}$ of peptone saline containing either $10^{8}$ viable Rs Margaree (ㅁ) , $10^{8}$ viable Rs Miramichi $(\mathbf{\Lambda}), 5 \times 10^{6}$ viable Rs Margaree (ם) or $5 \times 10^{6}$ viable Rs Margaree (O)

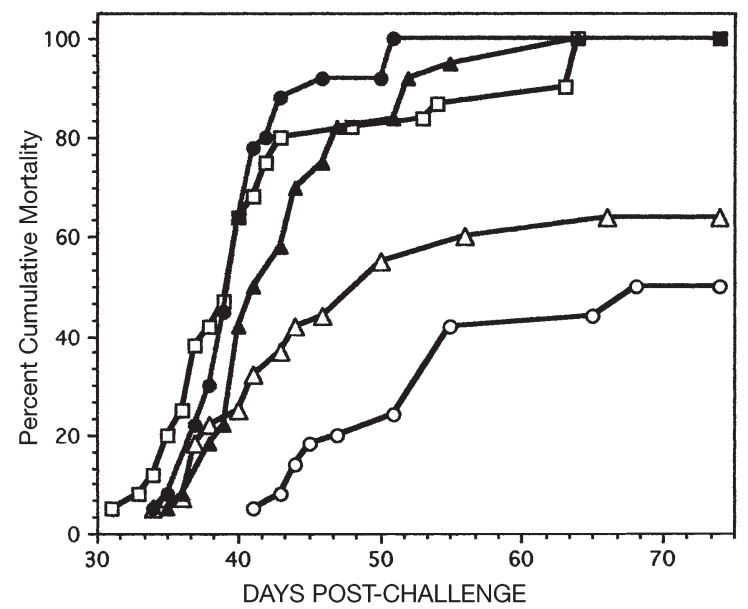

Fig. 2. Intraperitoneal (IP) challenge of vaccinated Atlantic salmon Salmo salar with Rs Margaree, Trial one. Fifty gram Atlantic salmon, with no prior history of BKD, were anaesthetized with 2-phenoxyethanol and immunized with a single IP dose of one of the following: (1) $10^{8}$ formalin $(0.5 \%)$-killed Rs Margaree in peptone saline containing Complete Freund's adjuvant (๑) (Difco), (2) $5 \times 10^{6}$ live cells of Rs TSA1 in peptone saline (O), (3) $5 \times 10^{6}$ live cells of Rs BHI in peptone saline $(\Delta)$, (4) $5 \times 10^{6}$ live cells of Rs MT239 in peptone saline $(\mathbf{\Delta})$ or (5) peptone saline alone ( $\square$ ). The salmon were held in 1 tank containing fresh water at 13 to $15^{\circ} \mathrm{C}$. All groups contained 25 fish. After vaccination, the fish were allowed to rest for 1 mo. At this time, all fish of each group were again anaesthetized with 2-phenoxyethanol $(1: 7000 ; \mathrm{v} / \mathrm{v})$ and individually challenged with $5 \times 10^{6}$ live cells of Rs Margaree in peptone saline. After being challenged, the fish were observed twice daily for mortalities for $75 \mathrm{~d}$ 


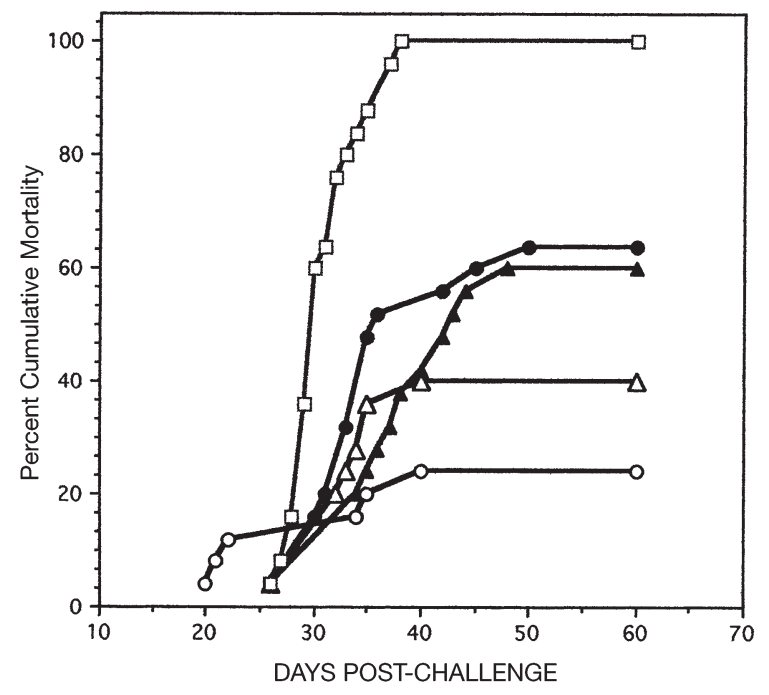

Fig. 3. Intraperitoneal (IP) challenge of vaccinated Atlantic salmon Salmo salar with Rs Margaree, Trial 2. Fifty gram Atlantic salmon, with no prior history of BKD, were immunized with a single IP dose of 1 of the following: (1) $10^{8}$ formalin $(0.5 \%)$-killed Rs Margaree in peptone saline containing Complete Freund's adjuvant (•) (Difco), (2) $5 \times 10^{6}$ live cells of Rs TSA1 in peptone saline (O), (3) $5 \times 10^{6}$ live cells of Rs BHI in peptone saline $(\Delta)$, (4) $5 \times 10^{6}$ live cells of Rs MT239 in peptone saline ( $\boldsymbol{\Delta})$ or (5) peptone saline alone ( $\square$ ). The salmon were held in one tank containing fresh water at 13 to $15^{\circ} \mathrm{C}$. All groups contained 25 fish. After vaccination, the fish were allowed to rest for $1 \mathrm{mo}$. At this time, all fish of each group were again anaesthetized with 2-phenoxyethanol $(1: 7000 ; \mathrm{v} / \mathrm{v})$ and individually challenged with $5 \times$ $10^{6}$ live cells of Rs Margaree in peptone saline. After being challenged, the fish were observed twice daily for mortalities for $60 \mathrm{~d}$

\section{DISCUSSION}

To date, both the Rs TSA1 and Rs BHI1 strains have been cultured on either TSA or BHI agar for more than 25 bacterial transfers. Both strains continue to remain hydrophobic and still produce the p57 cell surface antigen (data not shown; Griffiths et al. 1998), and we have never observed them to revert back to their original nutritional wild type. Recently, it has also been independently shown by Grayson et al. (1999) that Rs TSA1 produces the msa, hly and rsh genes. Under molecular analysis, this strain did not appear to be different from the other wild-type Renibacterium salmoninarum strains that were examined (Grayson et al. 1999). Except for the fact that Rs TSA1 and Rs BHI1 grow on TSA and BHIA (unlike their parental strains), and therefore do not have the absolute L-cysteine requirement necessary for the typical virulent strains, we know of no other phenotypic difference that can be used to distinguish them from wild-type $R$. salmoninarum. Furthermore, we do not know why they are avirulent. On a number of occasions, from a number of different isolates, we have isolated $R$. salmoninarum that can grow on TSA.

Previously Bruno (1988) has shown that Rs MT-239 has reduced virulence in rainbow trout Oncorhynchus mykiss and has suggested that the loss of p57 (or bacterial cell hydrophobicity) was associated with reduced virulence. Recent data have shown that Rs MT-239 does produce p57. However the protein shows little attachment (assembly?) to the bacterium's cell surface. Thus, cell-associated p57 is not detected in the typical amounts seen with other isolates of Renibacterium salmoninarum (Senson \& Stevenson 1999). The data presented here for Rs TSA1 and Rs BHI1 demonstrate that nutritionally mutant strains can produce p57 on their surface, and yet be avirulent. This suggests that although p57 may be an important virulence factor, another as of yet uncharacterized factor must also be present. Thus, $R$. salmoninarum must have multiple virulence factors that must be expressed in order for the bacterium to cause disease in salmon.

Until recently, researchers have had limited success in the development of a BKD vaccine. Piganelli et al. (1999) have had success protecting coho salmon with an oral vaccine consisting of formalin-killed Renibacterium salmoninarum with the p57 antigen removed by heat treatment. Griffiths et al. (1998) have shown some protection against $R$. salmoninarum in Atlantic salmon using both live Arthrobacter and live Rs TSA1 vaccines. These authors demonstrated that after $14 \mathrm{wk}$ only $31 \%$ of the live Rs TSA1 vaccinated Atlantic salmon $(80 \mathrm{~g})$ were culture positive for $R$. salmoninarum, whereas in the unvaccinated fish, $85 \%$ were culture positive. However in their study, the challenge strain of R. salmoninarum failed to kill either their nonvaccinated or their vaccinated groups of salmon. In order to extrapolate protection, Griffiths et al. (1998) were forced to compare relative tissue levels of the bacterium in non-vaccinated groups versus vaccine groups. The data presented in our study strengthen and confirm the findings of Griffiths et al. (1998), and clearly demonstrate that vaccinating Atlantic salmon with the live Rs TSA1 reduces mortalities from a lethal challenge. Our data also demonstrate that different attenuated $R$. salmoninarum do not provide the same level of protection against a lethal challenge of $R$. salmoninarum. Although the protection that is seen after the vaccination with live, attenuated Rs TSA1 is not complete, it is encouraging for those that hope to develop a vaccine to prevent this salmonid disease. Further investigations into the mechanisms for the avirulence of Rs TSA1 may permit the development of genetically defined mutants leading to their potential use as vaccines. 
Acknowledgements. This project was funded in part by the Atlantic Fisheries Adjustment Program of the Canadian Department of Fisheries and Oceans and by USDA National Research Initiative Competitive Grants Program award 9537204-2236 to J.G.D.

\section{LITERATURE CITED}

Amend DF (1981) Potency testing of fish vaccines. Dev Biol Stand 49:447-454

Austin B, Embley TM, Goodfellow M (1983) Selective isolation of Renibacterium salmoninarum. FEMS Microbiol Lett 17:111-114

Bandin I, Santos Y, Bruno DW, Raynard RS, Toranzo AE, Barja JL (1991) Lack of biological activities in the extracellular products of Renibacterium salmoninarum. Can J Fish Aquat Sci 48:421-425

Bruno DW (1988) The relationship between auto-aggregation, cell surface hydrophobicity and virulence of the fish pathogen Renibacterium salmoninarum. FEMS Microbiol Lett 51:135-140

Bruno DW, Munro ALS (1986) Uniformity in the biochemical properties of Renibacterium salmoninarum isolates obtained from several sources. FEMS Microbiol Lett 33: $247-250$

Daly JG, Stevenson RMW (1985) Charcoal agar, a new growth medium for the fish disease bacterium Renibacterium salmoninarum. Appl Environ Microbiol 50: 868-871

Daly JG, Stevenson RMW (1987) Hydrophobic and haemagglutinating properties of Renibacterium salmoninarum. J Gen Microbiol 133:3575-3580

Daly JG, Stevenson RMW (1989) Agglutination of salmonid spermatozoa by Renibacterium salmoninarum. J Aquat Anim Health 1:163-164

Daly JG, Stevenson RMW (1990) Characterization of the Renibacterium salmoninarum haemagglutinin. J Gen Microbiol 136:949-954

Daly JG, Stevenson RMW (1993) Nutritional requirements of Renibacterium salmoninarum on agar and in broth media. Appl Environ Microbiol 59:2178-2183

Editorial responsibility: David Bruno, Aberdeen, Scotland, UK
Evelyn TPT (1977) An improved growth medium for the kidney disease bacterium and some notes on using the medium. Bull Off Int Epizoot 87:511-513

Evelyn TPT (1993) Bacterial kidney disease - BKD. In: Inglis V, Roberts RJ, Bromage N (eds) Bacterial diseases of fish. Blackwell Scientific Publications, Oxford, p 177-195

Evelyn TPT (1996) Infection and disease. In: Iwama G Nakanishi $\mathrm{T}$ (eds) The fish immune system. Fish physiology, Vol 15. Academic Press, New York, p 339-366

Fryer JL, Lannan C (1993). The history and current status of Renibacterium salmoninarum, the causative agent of bacterial kidney disease in Pacific salmon. Fish Res 17:15-33

Grayson TH, Cooper LF, Atienzar FA, Knowles MR, Gilpin ML (1999) Molecular differentiation of Renibacterium salmoninarum isolates from worldwide locations. Appl Environ Microbiol 65:961-968

Griffiths SG, Melville KJ, Salonius K (1998) Reduction of Renibacterium salmoninarum culture activity in Atlantic salmon following vaccination with avirulent strains. Fish Shellfish Immunol 8:607-619

Gutenberger SK (1993) Phylogeny and intracellular studies of Renibacterium salmoninarum. PhD thesis, Oregeon State University, Corvallis

MacIntosh D, Flano E, Grayson TH, Gilpin ML, Austin B (1997) Production of putative virulence factors by Renibacterium salmoninarum grown in cell culture. Microbiology 143:3349-3356

Piganelli JD, Wiens GD, Zhang JA, Christenson JM, Kaattari SL (1999) Evaluation of a whole cell, p57 ${ }^{-}$vaccine against pathogen Renibacterium salmoninarum. Dis Aquat Org 39:37-44

Senson PR, Stevenson RMW (1999) Production of the $57 \mathrm{kDa}$ major surface antigen by a non-agglutinating strain of the fish pathogen Renibacterium salmoninarum. Dis Aquat Org 38:23-31

Weins GD, Kaattari SL (1991) Monoclonal antibody characterization of a leukoagglutinin produced by Renibacterium salmoninarum. Infect Immunol 58:631-637

Young CL, Chapman GB (1978) Ultrastructural aspects of the causative agent and renal histopathology of bacterial kidney disease in brook trout (Salvelinus fontinalis). J Fish Res Board Can 35:1234-1248

Submitted: April 25, 2000; Accepted: November 14, 2000 Proofs received from author(s): February 19, 2001 